\title{
Chemical composition of the mushroom Meripilus giganteus Karst. and bioactive properties of its methanolic extract
}

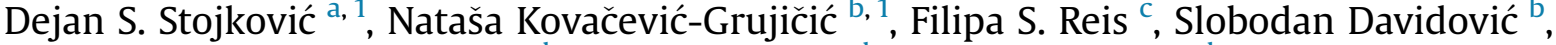 \\ Lillian Barros ${ }^{c}$, Jelena Popović ${ }^{b}$, Isidora Petrović ${ }^{b}$, Aleksandar Pavić $^{b}$, \\ Jasmina Glamočlija ${ }^{\text {a }}$, Ana Ćirić a ${ }^{\text {, Milena Stevanović }}{ }^{\text {b, }}{ }^{* * *}$, Isabel C.F.R. Ferreira ${ }^{\text {c, }}{ }^{* *}$, \\ Marina Soković ${ }^{\text {, }}$ " \\ a Institute for Biological Research “Siniša Stanković", Department of Plant Physiology, University of Belgrade, Bulevar Despota Stefana 142, 11000 Belgrade, \\ Serbia \\ ${ }^{\mathrm{b}}$ Institute of Molecular Genetics and Genetic Engineering, University of Belgrade, Vojvode Stepe 444a, PO Box 23, 11010 Belgrade, Serbia \\ ${ }^{\mathrm{c}}$ Mountain Research Centre (CIMO), School of Agriculture, Polytechnic Institute of Bragança, Campus de Santa Apolónia, Apartado 1172, $5300-253$ \\ Bragança, Portugal
}

\section{A R T I C L E I N F O}

\section{Article history:}

Received 24 November 2016

Received in revised form

4 January 2017

Accepted 16 January 2017

Available online 17 January 2017

\section{Keywords:}

Meripilus giganteus Karst.

Antioxidant activity

Antimicrobial activity

Antitumor activity

Apoptosis

\begin{abstract}
A B S T R A C T
Wild Meripilus giganteus Karst belongs to the order Polyporales, in which some members are known to possess a wide range of pharmacological properties. M. giganteus showed to be rich in carbohydrates $(74.49 \mathrm{~g} / 100 \mathrm{~g})$ and proteins $(15.94 \mathrm{~g} / 100 \mathrm{~g})$, presenting low fat content $(1.51 \mathrm{~g} / 100 \mathrm{~g})$. Chemical composition was determined by using chromatographic techniques. Also, various bioactive compounds were detected including all four tocopherol isoforms with $\delta$ - and $\gamma$-tocopherols being predominant (123.35 and $77.80 \mu \mathrm{g} / 100 \mathrm{~g}$, respectively); five organic acids (oxalic, malic, quinic, citric and fumaric acids) with predominant malic acid ( $3.17 \mathrm{~g} / 100 \mathrm{~g}$ ); and three phenolic acids and related compounds ( $p$ hydroxybenzoic, $p$-coumaric and cinnamic acids; 1010,2420 and $340 \mu \mathrm{g} / 100 \mathrm{~g}$, respectively). M. giganteus methanolic extract exhibited antioxidant activity tested by five different assays with the strongest potential in TBARS assay (EC $500.31 \mathrm{mg} / \mathrm{mL}$ ); and antimicrobial activities (MIC/MBC $0.0125-5 \mathrm{mg} / \mathrm{mL} ; \mathrm{MIC}$ ) MFC $0.025-0.4 \mathrm{mg} / \mathrm{mL}$ ). Furthermore, treatment of cervical carcinoma cell line (HeLa) led to reduction in cell's viability in MTT assay ( $\left(\mathrm{IC}_{50} 0.41 \mathrm{mg} / \mathrm{mL}\right.$ after $48 \mathrm{~h}$ ), induced process of apoptosis and inhibited cell's migration in vitro. The analysed extract was not toxic for zebrafish embryos (at $0.5 \mathrm{mg} / \mathrm{mL}$ ), indicating its biosafety and potential application as a dietary supplement in chemoprevention.
\end{abstract}

() 2017 Elsevier Ltd. All rights reserved.

\section{Introduction}

Besides their high nutritional value (Kalač, 2013), mushrooms possess a wide variety of beneficial effects to human health, with special emphasis on pharmacological properties such as antioxidant (Ferreira, Barros, \& Abreu, 2009), antimicrobial (Alves et al., 2013) and antitumor (Popović, Živković, Davidović, Stevanović, \& Stojković, 2013) activities. Among the bioactive constituents in

\footnotetext{
* Corresponding author.

** Corresponding author.

*** Corresponding author

E-mail addresses: milenastevanovic@imgge.bg.ac.rs (M. Stevanović), iferreira@ ipb.pt (I.C.F.R. Ferreira), mris@ibiss.bg.ac.rs (M. Soković).

1 These authors contributed equally to this work.
}

medicinal and edible mushrooms, tocopherols, fatty acids, organic acids, polyphenols, polysacharides and proteins are the most frequently reported. Bioactivity of tocopherols includes antioxidant capacity (Ferreira et al., 2009) that confers ability to prevent diseases correlated with increased formation of free radicals and oxidative stress. Also, polyunsaturated fatty acids (PUFAs) seem to be endogenous mediators for cell signaling, being involved in the regulation of gene expression and other biological processes (Choque, Catheline, Rioux, \& Legrand, 2014). Furthermore, phenolic compounds are known to exert multiple biological effects, including antioxidant, antitumor, antimutagenic and antibacterial properties (Kancheva \& Kasaikina, 2013).

Reactions leading to the production of free radicals namely, reactive oxigen species (ROS), reactive nitrosative species (RNS) and reactive sulphur species (RSS) have been linked to many severe 
diseases, such as cancer. Therefore, searching for novel sources of antioxidants from natural origin, being able to neutralize free radicals, is one of the major concerns in the field of cancer chemoprevention. In addition, more than $15 \%$ of malignancies worldwide have been related to an infectious cause (Mager, 2006). Although there are effective ways and reliable drugs to treat microbial infections, some bacteria and fungi develop mechanisms to overcome the effects of commercial antimicrobial agents, mostly due to their misuse. Proper treatment of microbial infections is leading to lower cancer occurrence and this should influence the well-being of human population (Assaf et al., 2013). Additionally, mycotherapy of cancer is emerging as a rapidly growing and promising discipline that involves the study of cancer chemopreventive and anticancer properties of mushrooms extracts and their bioactive compounds (Popović et al., 2013).

Meripilus giganteus Karst. is a wild growing basidiomycete with an edible fruiting body, belonging to the family Meripilaceae. It is a parasitic species on trees, being also characterized as saprobic. It is frequently found on Quercus and Fagus species, but it can also be found on some hardwoods and coniferous species. M. giganteus is mainly distributed in northern hemisphere, in Europe, Turkey, Iran and northern Asia (Schmidt, 2006). So far, reports on chemical composition of $M$. giganteus growing wild in Serbia, as well as on bioactive properties of its methanolic extract are very scarce (Karaman, Jovin, Malbaša, Matavuly, \& Popovic, 2010; Karaman, Kaisarevic, Somborski, Kebert, \& Matavulj, 2009). The present study aims to characterize the chemical composition of $M$. giganteus and to evaluate its biological properties namely, antioxidant potential, antimicrobial activity and the effect on cancer cell's viability, apoptosis and migration in vitro. Finally, its toxicity was evaluated on zebrafish.

\section{Materials and methods}

\subsection{Samples}

The samples of wild growing Meripilus giganteus Karst. were collected in Bojčinska forest, Belgrade, Serbia, in autumn 2012, and authenticated by Dr. Jasmina Glamočlija (Institute for Biological Research). A voucher specimen was deposited at the Fungal Collection Unit of the Mycological Laboratory, Department for Plant Physiology, Institute for Biological Research "Siniša Stanković", Belgrade, Serbia, under the number Mg 181 2012. The samples were lyophilized (LH Leybold, Lyovac GT2, Frenkendorf), reduced to a fine dried powder (20 mesh) and stored in a desiccator, protected from light, until further analysis.

\subsection{Standards and reagents}

Acetonitrile 99.9\%, $n$-hexane $95 \%$ and ethyl acetate $99.8 \%$ were of HPLC grade from Fisher Scientific (Lisbon, Portugal). The fatty acids methyl ester (FAME) reference standard mixture 37 (standard 47885-U) was purchased from Sigma (St. Louis, MO, USA), as also were other individual fatty acid isomers, trolox (6-hydroxy-2,5,7,8tetramethylchroman-2-carboxylic acid), tocopherol and sugar standards. Phenolic compound standards were from Extrasynthese (Genay, France). Racemic tocol, $50 \mathrm{mg} / \mathrm{mL}$, was purchased from Matreya (Pleasant Gap, PA, USA). 2,2-Diphenyl-1- picrylhydrazyl (DPPH) was obtained from Alfa Aesar (Ward Hill, MA, USA). Dulbecco's modified Eagle's medium (DMEM), fetal bovine serum (FBS) and MEM non-essential amino acids (NEAA) were obtained from Invitrogen (NY, USA). 3-(4,5-Dimethylthiazol-2yl)-2,5diphenyltetrazolium bromide (MTT), paraformaldehyde (PFA) and dimethylsulfoxide (DMSO) were from Merck (KGaA, Germany). 4',6-Diamidino-2-phenylindole dihydrochloride (DAPI) and propidium iodide (PI) were obtained from Sigma (St. Louis, MO, USA) and doxorubicin from Pfizer Inc (NY, USA). APOPTEST ${ }^{\text {TM-FITC }}$ kit was obtained from Dako (Agilent Technologies Inc., Denmark). Mueller-Hinton agar (MH) and malt agar (MA) were obtained from the Institute of Immunology and Virology, Torlak (Belgrade, Serbia). Water was treated in a Milli-Q water purification system (TGI Pure Water Systems, Greenville, SC, USA).

\subsection{Preparation of the M. giganteus methanolic extract}

Samples $(\sim 5 \mathrm{~g})$ were extracted by stirring with $150 \mathrm{~mL}$ of methanol $\left(25{ }^{\circ} \mathrm{C}\right.$ at $\left.150 \mathrm{rpm}\right)$ for $1 \mathrm{~h}$ and subsequently filtered through Whatman No. 4 paper. The residue was then extracted with an additional portion of methanol. The combined methanolic extracts were evaporated under reduced pressure (rotary evaporator Büchi R-210; Flawil, Switzerland) to dryness (Heleno, Barros, Sousa, Martins, \& Ferreira, 2010). The extract was redissolved in i) methanol (final concentration $20 \mathrm{mg} / \mathrm{mL}$ ) for antioxidant activity assays, ii) $30 \% \mathrm{EtOH}$ (final concentration $1.5 \mathrm{mg} / \mathrm{mL}$ ) for antimicrobial activity assays and for cytotoxic activity evaluation $(80 \mathrm{mg} /$ $\mathrm{mL}$ final concentration). The final solutions were further diluted to different concentrations to be submitted to distinct bioactivity evaluation in vitro assays. The results were expressed in i) $\mathrm{EC}_{50}$ values (sample concentration providing $50 \%$ of antioxidant activity or 0.5 of absorbance in the reducing power assay) for antioxidant activity; ii) MIC (Minimum inhibitory concentration) and MBC/MFC (Minimum bactericidal concentration/Minimum fungicidal concentration) values for in vitro antimicrobial activity iii) $\mathrm{IC}_{50}$ value (sample concentration providing 50\% inhibition of cell growth in MTT test) for cytotoxicity assay.

\subsection{Chemical characterization of the M. giganteus methanolic extract - bioactive compounds}

Tocopherols were determined following a procedure previously described by the authors (Heleno et al., 2010) using HPLCfluorescence. The compounds were identified by chromatographic comparisons with authentic standards. Quantification was based on the fluorescence signal response of each standard, using the IS (tocol) method and by using calibration curves obtained from commercial standards of each compound: $\alpha$-tocopherol $\left(\mathrm{y}=1.295 \mathrm{x} ; R^{2}=0.991\right) ; \beta$-tocopherol $\left(\mathrm{y}=0.396 \mathrm{x} ; R^{2}=0.992\right) ; \gamma$ tocopherol $\left(\mathrm{y}=0.567 \mathrm{x} ; R^{2}=0.991\right) ; \delta$-tocopherol $(\mathrm{y}=0.678 \mathrm{x}$; $\left.R^{2}=0.992\right)$. The results were expressed in $\mu \mathrm{g}$ per $100 \mathrm{~g}$ of dry weight (dw). Organic acids were determined by ultrafast liquid chromatography coupled to a photodiode array detector (UFLCPAD), following a procedure previously described by the authors (Barros, Pereira, \& Ferreira, 2013). The organic acids found were quantified by comparison of the area of their peaks recorded at $215 \mathrm{~nm}$ with calibration curves obtained from commercial standards of each compound: oxalic acid $\left(\mathrm{y}=1 \times 10^{7} \mathrm{x}+96178\right.$; $\left.R^{2}=0.999\right)$; quinic acid $\left(\mathrm{y}=601768 \mathrm{x}+8853.2 ; \mathrm{R}^{2}=1\right)$; malic acid $\left(\mathrm{y}=952269 \mathrm{x}+17803 ; \mathrm{R}^{2}=1\right)$ and fumaric acid $\left(\mathrm{y}=172760 \mathrm{x}+52193 ; R^{2}=0.999\right.$. The results were expressed in $\mathrm{g}$ per $100 \mathrm{~g}$ of dry mushroom (dw). Phenolic compounds were determined by the same methodology using $280 \mathrm{~nm}$ and $370 \mathrm{~nm}$ as preferred wavelengths, according to a procedure previously described by the authors (Barros, Dueñas, Ferreira, Baptista, \& Santos-Buelga, 2009). The phenolic compounds were characterized according to their UV and mass spectra and retention times, and comparison with authentic standards when available. For the quantitative analysis of phenolic compounds, a calibration curve was obtained by injection of known concentrations $(5-80 \mu \mathrm{g} / \mathrm{mL})$ of different standards compounds: p-hydroxybenzoic acid $\left(\mathrm{y}=16420 \mathrm{x}+12914 ; \quad R^{2}=0.9999\right) ; p$-coumaric acid 
$\left(\mathrm{y}=51195 \mathrm{x}+1 \times 10^{6} \mathrm{x} ; R^{2}=0.992\right) ;$ cinnamic acid $\left(\mathrm{y}=86366 \mathrm{x}+88451 ; R^{2}=0.999\right)$. The results were expressed as $\mu \mathrm{g}$ per $100 \mathrm{~g}$ of dry weight (dw).

\subsection{Antioxidant activity}

DPPH radical-scavenging activity was evaluated by using an ELX800 microplate reader (Bio-Tek Instruments, Inc; Winooski, VT, USA), and calculated as a percentage of DPPH discolouration using the formula: $\left[\left(A_{D P P H}-A_{S}\right) / A_{D P P H}\right] \times 100$, where $A_{S}$ is the absorbance of the solution containing the sample at $515 \mathrm{~nm}$, and $A_{D P P H}$ is the absorbance of the DPPH solution. Reducing power was evaluated by two different assays: Ferricyanide/Prussian blue assay, which determines the capacity to convert $\mathrm{Fe}^{3+}$ into $\mathrm{Fe}^{2+}$, measuring the absorbance at $690 \mathrm{~nm}$ in the microplate reader mentioned above; Folin-Ciocalteu assay: the colour development was measured at $765 \mathrm{~nm}$ (Analytikjena spectrophotometer; Jena, Germany). Gallic acid was used to obtain the standard curve and the reduction of Folin-Ciocalteu reagent by the samples was expressed as mg of gallic acid equivalents (GAE) per g of extract (Heleno et al., 2010). Inhibition of $\beta$-carotene bleaching was evaluated though the $\beta$ carotene/linoleate assay; the neutralization of linoleate free radicals avoids $\beta$-carotene bleaching, measured at $470 \mathrm{~nm}$ and calculated by the formula: $\beta$-carotene absorbance after $2 \mathrm{~h}$ of assay/ initial absorbance) $\times 100$ (Heleno et al., 2010). Lipid peroxidation inhibition in porcine (Sus scrofa) brain homogenates was evaluated by the decreasing in thiobarbituric acid reactive substances (TBARS); the colour intensity of the malondialdehydethiobarbituric acid (MDA-TBA) was measured by its absorbance at $532 \mathrm{~nm}$; the inhibition ratio (\%) was calculated using the following formula: $[(A-B) / A] \times 100 \%$, where $A$ and $B$ were the absorbances of the control and the sample solution, respectively (Heleno et al., 2010). Trolox was used as a positive control in all of the antioxidant assays.

\subsection{Antimicrobial properties}

The following Gram-negative bacteria were used: Escherichia coli (ATCC 35210), Pseudomonas aeruginosa (ATCC 27853), Salmonella typhimurium (ATCC 13311), Enterobacter cloacae (ATCC 35030) and the following Gram-positive bacteria: Staphylococcus aureus (ATCC 6538), Bacillus cereus (clinical isolate), Micrococcus flavus (ATCC 10240), and Listeria monocytogenes (NCTC 7973).

For the antifungal bioassays, microfungi were used: Aspergillus fumigatus (1022), Aspergillus ochraceus (ATCC 12066), Aspergillus versicolor (ATCC 11730), Aspergillus niger (ATCC 6275), Penicillium funiculosum (ATCC 36839), Penicillium ochrochloron (ATCC 9112), Trichoderma viride (IAM 5061), and Penicillium aurantiogriseum (food isolate). The organisms were obtained from the Mycological Laboratory, Department of Plant Physiology, Institute for Biological Research "Siniša Stanković”, Belgrade, Serbia.

In order to investigate the antimicrobial activity of the M. giganteus methanolic extract, a modified microdilution technique was used (CLSI, 2009). Minimum inhibitory concentration (MIC) determinations were performed by a serial dilution technique using 96-well microtiter plates. The minimum bactericidal concentrations (MBCs) and minimum fungicidal concentrations (MFCs) were determined by serial subcultivation of a $2 \mu \mathrm{L}$ sample into microtiter plates containing $100 \mu \mathrm{L}$ of broth per well and further incubation for $48 \mathrm{~h}$ at $37^{\circ} \mathrm{C}$ or $72 \mathrm{~h}$ at $28^{\circ} \mathrm{C}$. The lowest concentration with no visible growth was defined as MBC/MFC, respectively, indicating $99.5 \%$ killing of the original inoculum. Streptomycin (streptomycin sulfate (ICN-Galenika, Belgrade, Serbia) and ampicillin (Panfarma, Belgrade, Serbia) were used as positive controls in antibacterial assay, while commercial fungicides, bifonazole (Srbolek, Belgrade, Serbia) and ketoconazole (Zorkapharma, Šabac, Serbia), were used as positive controls in antifungal tests ( $1 \mathrm{mg} / \mathrm{ml}$ in sterile physiological saline). $30 \% \mathrm{EtOH}$ was used as a negative control.

\subsection{Evaluation of cytotoxicity by MTT assay}

Human cervical cancer cell line HeLa and human lung fibroblasts MRC- 5 were cultured in DMEM supplemented with $1 \%$ NEAA and $10 \% \mathrm{FBS}$ at $37{ }^{\circ} \mathrm{C}$ in a humidified incubator with $5 \% \mathrm{CO}_{2}$. Cell viability was determined by the colorimetric MTT assay. Briefly, 24 h before treatment $4 \times 10^{3}$ HeLa cells/well and $10^{4}$ MRC- 5 cells/ well were seeded in 96-well plates. Cells were then treated for 24 and $48 \mathrm{~h}$ with various concentrations of $M$. giganteus methanolic extract (prepared by dilution from the inicial stock solution, $80 \mathrm{mg} /$ $\mathrm{mL}$ ) or doxorubicin as a positive reference compound. Relative cell viability was obtained by measuring the absorbance at $550 \mathrm{~nm}$ in a Multiscan RC microplate reader (Thermo Labsystems, Helsinki, Finland). Concentrations that caused $50 \%\left(\mathrm{IC}_{50}\right)$ or $80 \%\left(\mathrm{IC}_{80}\right)$ of inhibition of cells growth after 24 and $48 \mathrm{~h}$ of treatment were calculated based on their survival rate compared with control cells treated with vehicle only (30\% ethanol).

\subsection{Double DAPI and PI staining of live cells}

Control cells and cells treated with $\mathrm{IC}_{50}$ and $\mathrm{IC}_{80}$ concentrations of extract were grown for 24 and 48 h on coverslips in 6-well plates. After washing three times in phosphate buffered saline (PBS), the cells were incubated in PBS containing $1 \mu \mathrm{g} / \mathrm{mL}$ of DAPI and $5 \mu \mathrm{g} / \mathrm{mL}$ of PI for 10 min at RT. After staining, cells were washed three times in PBS and fixed with 4\% PFA for 15 min. Cells were examined under the Zeiss Axiovert inverted fluorescent microscope (Carl Zeiss Foundation, Oberkochen, Germany) equipped with AxioVision4.8 software, using 365/550 nm excitation; the fluorescence emission was measured at $445 \mathrm{~nm}$ for DAPI and $605 \mathrm{~nm}$ for PI with a $20 \times$ objective.

\subsection{Detection of apoptosis by a double staining method with Annexin V-FITC and PI}

Apoptosis assays were conducted using the APOPTEST ${ }^{\text {TM-FITC }}$ kit according to the manufacturer's instructions. Briefly, control cells (treated with vehicle only) and cells treated with $\mathrm{IC}_{50}$ concentration of extract for $48 \mathrm{~h}$ were washed twice with cold PBS, resuspended in $1 \times$ Binding Buffer at a concentration of $1 \times 10^{6}$ cells $/ \mathrm{mL}$ and Annexin V-FITC and PI were added at the final concentrations of $25 \mathrm{ng} / \mathrm{mL}$ and $2.5 \mu \mathrm{g} / \mathrm{mL}$, respectively. The cells were gently mixed, incubated for $10 \mathrm{~min}$ in the dark at RT, and immediately analyzed (within $1 \mathrm{~h}$ ) by Partec CyFlow ${ }^{\mathbb{B}}$ Space (Partec $\mathrm{GmbH}$, Münster, Germany). The flow cytometer collected 100,000 events and analysis was performed using Flomax Software ${ }^{\circledR}$ Version 2.9.

\subsection{Wound-scratch migration assay}

$3 \times 10^{5}$ cells were plated in $35 \mathrm{~mm}$ dish, grown to confluence and treated with $\mathrm{IC}_{50}(24 \mathrm{~h})$ concentration of $M$. giganteus extract in serum reduced conditions (1\% FCS in DMEM) for $12 \mathrm{~h}$ before wound was made. Confluent cell monolayer was scratched with a $200 \mu \mathrm{l}$ tip, washed with serum-free medium to remove detached cells and finally fresh medium containing $1 \%$ FCS and M. giganteus extract was added. Cell migration into the wounded area was monitored using DM IL LED Inverted Microscope (Leica Microsystems, Wetzlar, Germany) and closure of the gap distance was quantified using Leica Application Suite V4.3.0. 


\subsection{In vivo zebrafish toxicity assay}

Assay is described in detail in Supplementary material.

\subsection{Statistical analysis}

Three samples were used and all the assays were carried out in triplicate. The results are expressed as mean values \pm standard deviation (SD) or standard error mean (SEM). The results were analyzed using one-way analysis of variance (ANOVA) followed by Tukey's HSD test with $\alpha=0.05$ or Student's $t$-test. This analysis was carried out using SPSS 22.0 program.

\section{Results and discussion}

3.1. Chemical composition of M. giganteus methanolic extractbioactive compounds

Bioactive compounds (tocopherols, organic and phenolic acids) identified in $M$. giganteus are presented in Table 1. All tocopherol isoforms were detected, but $\delta$ - and $\gamma$-tocopherols were the predominant isoforms (Table 1 and Fig. 1 A). On the other hand, $\beta$ - and $\alpha$-tocopherols were found at lower levels (Table 1 ). The most suitable sources of antioxidants, such as tocopherols, are provided by our diet, more than by antioxidant supplements (pills or tablets) (Bjelakovic, Nikolova, \& Gluud, 2014). M. giganteus represents a food source regarding intake of antioxidant tocopherols and to the best of our knowledge, tocopherols composition in this species was not previously reported in literature.

Quantitative values of organic acids identified in M. giganteus are given in Table 1 and its profile is represented in Fig. 1B. Malic acid, a dicarboxylic acid occurring naturally in all fruits, many vegetables and mushrooms, was the predominant organic acid, which was also observed for other mushroom species (Barros et al., 2013). Oxalic, citric, quinic and fumaric acids were also identified and quantified. Health-beneficial effects and bioactive properties of some organic acids are well-known and include antimicrobial, antioxidant and acidifying properties. Our results are in accordance to those published for other mushroom species (Barros et al., 2013).

Phenolic acids profile was provided in Fig. 1C $p$-Coumaric acid was the most abundant phenolic component identified in $M$. giganteus, while $p$-hydroxybenzoic and cinnamic acids were found at lower levels (Table 1 ). A previous study performed by Karaman et al. (2010) reported gallic $(675 \mu \mathrm{g} / \mathrm{g})$ and protocatechuic $(279 \mu \mathrm{g} / \mathrm{g})$ acids as the only phenolic compounds in $M$. giganteus, while $p$-coumaric acid was not detected. The observed differences might be attributed to different extraction methodologies or different maturity stages of fruiting bodies, among other factors.

Nutritional value, sugars composition and fatty acids profile are presented in Supplementary material.

\subsection{In vitro analysis of bioactive properties}

In order to analyze bioactive properties of M. giganteus methanolic extract, we have investigated antioxidant activity,
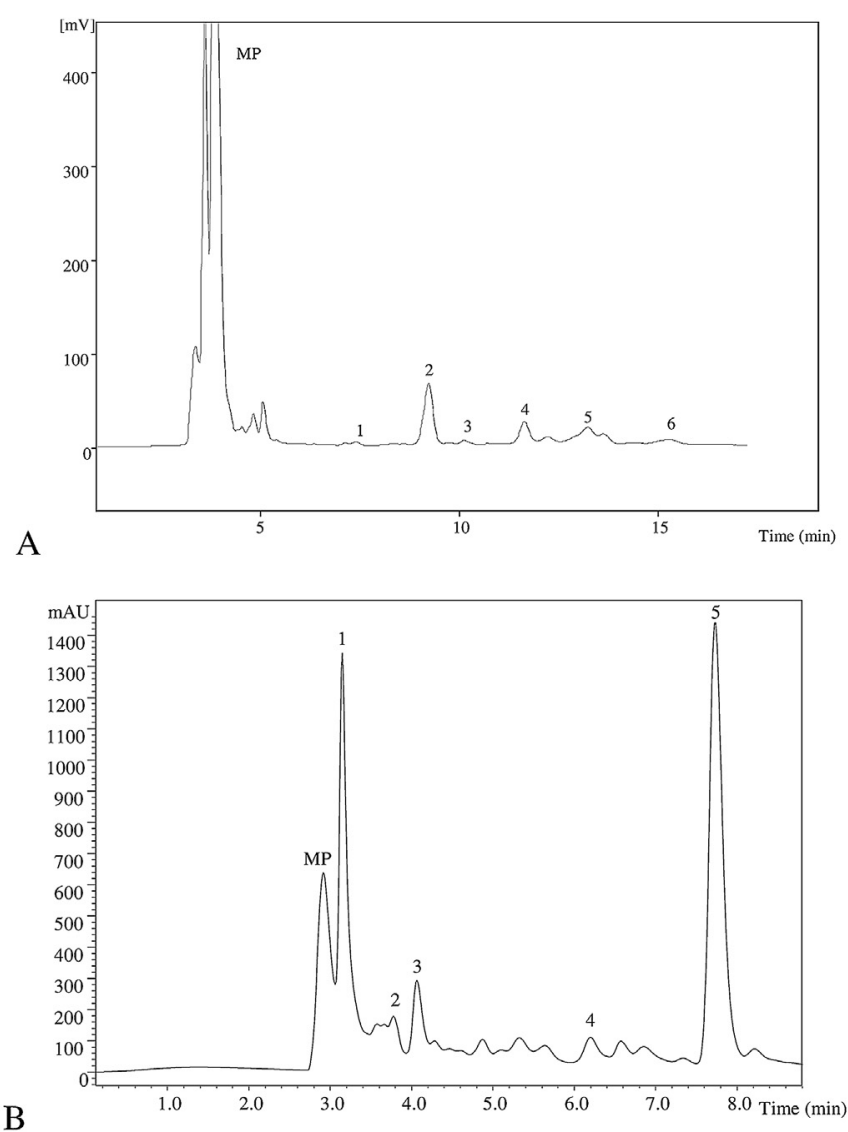

B

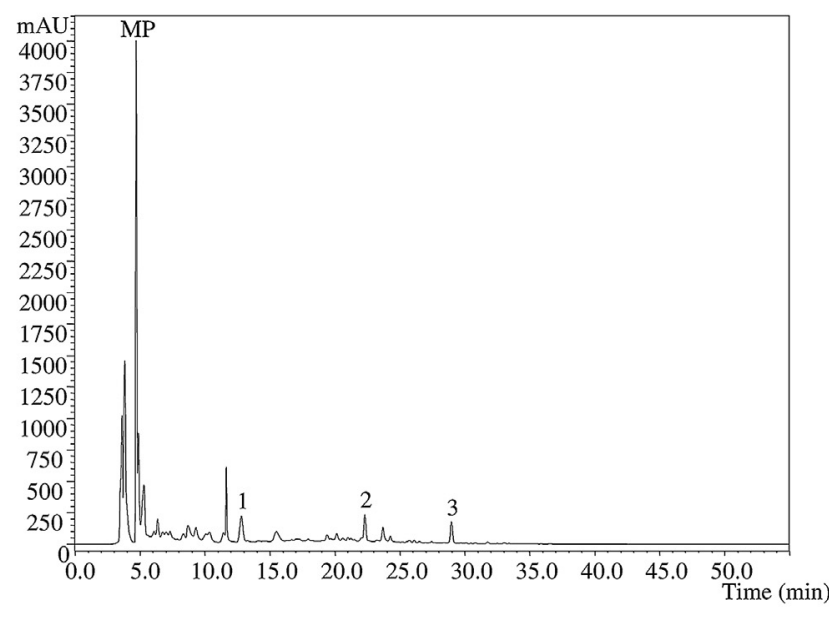

Fig. 1. Bioactive compounds identified in M. giganteus extract. A. Individual tocopherols chromatogram: 1 - $\alpha$-tocopherol; 2 - BHT; 3 - $\beta$-tocopherol; 4 - $\gamma$-tocopherol; 5 - $\delta$ tocopherol; 6-tocol (IS). B. Individual organic acids chromatogram: 1- oxalic acid; 2 quinic acid; 3- malic acid; 4- citric acid; 5- fumaric acid. C. Individual phenolic compounds chromatogram: 1- $p$-hydroxybenzoic acid; 2- $p$-coumaric acid; 3- cinnamic acid. MP- Mobile phase.

Table 1

Bioactive composition of $M$. giganteus on dry weight basis (mean \pm SD).

\begin{tabular}{|c|c|c|c|c|c|}
\hline Phenolic acids & $(\mu \mathrm{g} / 100 \mathrm{~g})$ & Tocopherols & $(\mu \mathrm{g} / 100 \mathrm{~g})$ & Organic acids & $(\mathrm{g} / 100 \mathrm{~g})$ \\
\hline p-Hydroxybenzoic acid & $1010 \pm 110$ & $\alpha$-tocopherol & $3.58 \pm 0.39$ & Oxalic acid & $1.32 \pm 0.02$ \\
\hline$p$-Coumaric acid & $2420 \pm 590$ & $\beta$-tocopherol & $9.05 \pm 0.13$ & Quinic acid & $0.48 \pm 0.03$ \\
\hline Cinnamic acid & $340 \pm 40$ & $\gamma$-tocopherol & $77.80 \pm 0.66$ & Malic acid & $3.17 \pm 0.01$ \\
\hline \multirow[t]{3}{*}{ Total phenolic acids* } & $3430 \pm 470$ & $\delta$-tocopherol & $123.35 \pm 40.11$ & Citric acid & $0.77 \pm 0.01$ \\
\hline & & Total tocopherols & $213.78 \pm 40.52$ & Fumaric acid & $0.16 \pm 0.00$ \\
\hline & & & & Total organic acids & $5.90 \pm 0.03$ \\
\hline
\end{tabular}


Table 2

Antioxidant properties of the M. giganteus methanolic extract (mean $\pm \mathrm{SD}$ ).

\begin{tabular}{ll}
\hline Antioxidant activity tests & Extract \\
\hline $\begin{array}{l}\text { Folin- Ciocalteu assay } \\
\text { (mg GAE/g extract) }\end{array}$ & $58.20 \pm 5.10$ \\
$\begin{array}{l}\text { Ferricyanide/Prussian blue assay }\left(\mathrm{EC}_{50} ; \mathrm{mg} / \mathrm{mL}\right) \\
\text { DPPH scavenging activity }\end{array}$ & $0.83 \pm 0.01$ \\
$\left(\mathrm{EC} \mathrm{C}_{50} ; \mathrm{mg} / \mathrm{mL}\right)$ & $2.08 \pm 0.06$ \\
$\beta-$ Carotene/linoleate assay & \\
$\left(\mathrm{EC} \mathrm{C}_{50} ; \mathrm{mg} / \mathrm{mL}\right)$ & $2.14 \pm 0.12$ \\
$\begin{array}{l}\mathrm{TBARS} \text { assay } \\
\left(\mathrm{EC} \mathrm{C}_{50} ; \mathrm{mg} / \mathrm{mL}\right)\end{array}$ & $0.31 \pm 0.02$ \\
\hline
\end{tabular}

Concerning the Folin-Ciocalteu assay, higher values mean higher reducing power; for the other assays, the results are presented in $\mathrm{EC}_{50}$ values, what means that higher values correspond to lower reducing power or antioxidant potential. $\mathrm{EC}_{50}$ : Extract concentration corresponding to $50 \%$ of antioxidant activity or 0.5 of absorbance for the Ferricyanide/Prussian blue assay. Trolox EC $\mathrm{E}_{50}$ values: $41 \mu \mathrm{g} / \mathrm{mL}$ (Ferricyanide/ Prussian blue assay), $42 \mu \mathrm{g} / \mathrm{mL}$ (DPPH scavenging activity), $18 \mu \mathrm{g} / \mathrm{mL}$ ( $\beta$-Carotene/ linoleate assay) and $23 \mu \mathrm{g} / \mathrm{mL}$ (TBARS assay).

antimicrobial properties, and the effect on cancer cell's viability, apoptosis and migration in vitro. Finally, toxicity testing of $M$. giganteus methanolic extract was performed on zebrafish embryos and these results are presented in Supplementary material.

\subsubsection{The antioxidant activity}

Since natural matrices with antioxidant activity important for the discovery of novel cancer chemopreventive and chemotherapeutic agents, we have analyzed the antioxidant activity of $M$. giganteus methanolic extract by five different in vitro assays
(Table 2).

Total phenolics content in the methanolic extract was $58.20 \mathrm{mg}$ $\mathrm{GAE} / \mathrm{g}$ of extract which is higher than the one reported by Karaman et al. (2010) (5.11 mg of chlorogenic acid equivalents/g of dry weight of $M$. giganteus). The obtained difference might be related to the different extraction methods used. Lipid peroxidation inhibition, evaluated by the decreasing in TBARS formation, gave the best result with $\mathrm{EC}_{50}$ value of $0.31 \mathrm{mg} / \mathrm{mL}$. For Ferricyanide/Prussian blue assay, $\mathrm{EC}_{50}$ value was $0.83 \mathrm{mg} / \mathrm{mL}$. On the other hand, DPPH scavenging activity and inhibition of $\beta$-carotene bleaching gave slightly higher results with $\mathrm{EC}_{50}$ values of $2.08 \mathrm{mg} / \mathrm{mL}$ and $2.14 \mathrm{mg} /$ $\mathrm{mL}$, respectively. DPPH scavenging activity of $M$. giganteus $70 \%$ methanolic extract was previously evaluated and the $\mathrm{EC}_{50}$ value was $0.155 \mathrm{mg} / \mathrm{mL}$ (Karaman et al., 2010). In the present study, the $\mathrm{EC}_{50} \mathrm{DPPH}$ scavenging activity value was significantly higher compared to the mentioned report and this difference might be explained by the different extraction conditions and drying processes applied to mushrooms (e.g. drying in the oven at $50^{\circ} \mathrm{C}$ ). As far as we know, this is the first study reporting antioxidant activity of pure methanolic extract of $M$. giganteus. The observed antioxidant activity may be related to the presence of phenolic acids and tocopherols, as generalized for other mushroom species (Ferreira et al., 2009).

\subsubsection{Antimicrobial properties}

Antibacterial and antifungal activity of the $M$. giganteus extract was assessed by microdilution methods, and the results are presented as MIC and MBC/MFC in Table 3. The most sensitive bacterial species to $M$. giganteus methanolic extract were $S$. aureus and

Table 3

In vitro antimicrobial activity of $M$. giganteus extract.

\begin{tabular}{|c|c|c|c|}
\hline Bacteria & $\begin{array}{l}\text { M. giganteus } \\
\mathrm{MIC} / \mathrm{MBC}(\mathrm{mg} / \mathrm{mL})\end{array}$ & $\begin{array}{l}\text { Streptomycin } \\
\text { MIC/MBC }(\mathrm{mg} / \mathrm{mL})\end{array}$ & $\begin{array}{l}\text { Ampicillin } \\
\text { MIC/MBC }(\mathrm{mg} / \mathrm{mL})\end{array}$ \\
\hline Staphylococcus aureus & $\begin{array}{l}0.0125 \pm 0.0008^{\mathrm{a}} \\
0.035 \pm 0.002^{\mathrm{a}}\end{array}$ & $\begin{array}{l}0.04 \pm 0.002^{\mathrm{b}} \\
0.09 \pm 0.003^{\mathrm{b}}\end{array}$ & $\begin{array}{l}0.25 \pm 0.000^{c} \\
0.37 \pm 0.0100^{c}\end{array}$ \\
\hline Bacillus cereus & $\begin{array}{l}0.0125 \pm 0.0008^{\mathrm{a}} \\
0.035 \pm 0.002^{\mathrm{a}}\end{array}$ & $\begin{array}{l}0.09 \pm 0.003^{b} \\
0.17 \pm 0.0100^{b}\end{array}$ & $\begin{array}{l}0.25 \pm 0.0100^{c} \\
0.37 \pm 0.007^{c}\end{array}$ \\
\hline Micrococcus flavus & $\begin{array}{l}0.60 \pm 0.03^{\mathrm{c}} \\
1.25 \pm 0.080^{\mathrm{b}}\end{array}$ & $\begin{array}{l}0.17 \pm 0.010^{\mathrm{a}} \\
0.34 \pm 0.010^{\mathrm{a}}\end{array}$ & $\begin{array}{l}0.25 \pm 0.0200^{\mathrm{b}} \\
0.37 \pm 0.000^{\mathrm{a}}\end{array}$ \\
\hline Listeria monocytogenes & $\begin{array}{l}0.30 \pm 0.000^{b} \\
0.60 \pm 0.010^{c}\end{array}$ & $\begin{array}{l}0.17 \pm 0.010^{\mathrm{a}} \\
0.34 \pm 0.010^{\mathrm{a}}\end{array}$ & $\begin{array}{l}0.37 \pm 0.010^{c} \\
0.49 \pm 0.010^{b}\end{array}$ \\
\hline Pseudomonas aeruginosa & $\begin{array}{l}0.60 \pm 0.020^{\mathrm{b}} \\
1.25 \pm 0.020^{\mathrm{b}}\end{array}$ & $\begin{array}{l}0.17 \pm 0.010^{\mathrm{a}} \\
0.34 \pm 0.000^{\mathrm{a}}\end{array}$ & $\begin{array}{l}0.74 \pm 0.000^{\mathrm{c}} \\
1.24 \pm 0.010^{\mathrm{b}}\end{array}$ \\
\hline Salmonella typhimurium & $\begin{array}{l}0.025 \pm 0.002^{\mathrm{a}} \\
0.035 \pm 0.002^{\mathrm{a}}\end{array}$ & $\begin{array}{l}0.17 \pm 0.010^{\mathrm{b}} \\
0.34 \pm 0.010^{\mathrm{b}}\end{array}$ & $\begin{array}{l}0.37 \pm 0.010^{c} \\
0.49 \pm 0.020^{c}\end{array}$ \\
\hline Escherichia coli & $\begin{array}{l}0.15 \pm 0.007^{\mathrm{a}} \\
0.60 \pm 0.000^{\mathrm{a}}\end{array}$ & $\begin{array}{l}0.17 \pm 0.007^{\mathrm{b}} \\
0.34 \pm 0.010^{\mathrm{b}}\end{array}$ & $\begin{array}{l}0.25 \pm 0.000^{c} \\
0.49 \pm 0.020^{c}\end{array}$ \\
\hline Enterobacter cloacae & $\begin{array}{l}2.50 \pm 0.070^{b} \\
5.00 \pm 0.000^{c}\end{array}$ & $\begin{array}{l}0.26 \pm 0.000^{\mathrm{a}} \\
0.52 \pm 0.007^{\mathrm{a}}\end{array}$ & $\begin{array}{l}0.37 \pm 0.010^{\mathrm{a}} \\
0.74 \pm 0.010^{\mathrm{b}}\end{array}$ \\
\hline Fungi & $\begin{array}{l}\text { M. giganteus } \\
\text { MIC/MFC (mg/mL) }\end{array}$ & $\begin{array}{l}\text { Bifonazole } \\
\text { MIC/MFC }(\mathrm{mg} / \mathrm{mL})\end{array}$ & $\begin{array}{l}\text { Ketoconazole } \\
\text { MIC/MFC }(\mathrm{mg} / \mathrm{mL})\end{array}$ \\
\hline Aspergillus fumigatus & $\begin{array}{l}0.10 \pm 0.010^{\mathrm{a}} \\
0.20 \pm 0.000^{\mathrm{a}}\end{array}$ & $\begin{array}{l}0.15 \pm 0.000^{\mathrm{b}} \\
0.20 \pm 0.020^{\mathrm{a}}\end{array}$ & $\begin{array}{l}0.20 \pm 0.010^{c} \\
0.50 \pm 0.020^{b}\end{array}$ \\
\hline Aspergillus versicolor & $\begin{array}{l}0.025 \pm 0.000^{\mathrm{a}} \\
0.050 \pm 0.002^{\mathrm{a}}\end{array}$ & $\begin{array}{l}0.10 \pm 0.010^{\mathrm{b}} \\
0.20 \pm 0.000^{\mathrm{b}}\end{array}$ & $\begin{array}{l}0.20 \pm 0.020^{c} \\
0.50 \pm 0.010^{c}\end{array}$ \\
\hline Aspergillus ochraceus & $\begin{array}{l}0.20 \pm 0.010^{\mathrm{a}} \\
0.40 \pm 0.010^{\mathrm{a}}\end{array}$ & $\begin{array}{l}0.15 \pm 0.007^{\mathrm{a}} \\
0.20 \pm 0.020^{\mathrm{a}}\end{array}$ & $\begin{array}{l}1.50 \pm 0.070^{\mathrm{b}} \\
2.00 \pm 0.100^{\mathrm{b}}\end{array}$ \\
\hline Aspergillus niger & $\begin{array}{l}0.30 \pm 0.010^{c} \\
0.40 \pm 0.000^{\mathrm{a}}\end{array}$ & $\begin{array}{l}0.15 \pm 0.000^{\mathrm{a}} \\
0.20 \pm 0.010^{\mathrm{b}}\end{array}$ & $\begin{array}{l}0.20 \pm 0.010^{b} \\
0.50 \pm 0.020^{c}\end{array}$ \\
\hline Trichoderma viride & $\begin{array}{l}0.05 \pm 0.002^{\mathrm{a}} \\
0.20 \pm 0.010^{\mathrm{a}}\end{array}$ & $\begin{array}{l}0.15 \pm 0.007^{\mathrm{a}} \\
0.20 \pm 0.000^{\mathrm{a}}\end{array}$ & $\begin{array}{l}1.00 \pm 0.070^{\mathrm{b}} \\
1.00 \pm 0.100^{\mathrm{b}}\end{array}$ \\
\hline Penicillium funiculosum & $\begin{array}{l}0.025 \pm 0.000^{\mathrm{a}} \\
0.400 \pm 0.010^{\mathrm{a}}\end{array}$ & $\begin{array}{l}0.20 \pm 0.010^{\mathrm{b}} \\
0.25 \pm 0.000^{\mathrm{b}}\end{array}$ & $\begin{array}{l}0.20 \pm 0.010^{b} \\
0.50 \pm 0.010^{c}\end{array}$ \\
\hline Penicillium ochrochloron & $\begin{array}{l}0.20 \pm 0.000^{\mathrm{a}} \\
0.40 \pm 0.020^{\mathrm{a}}\end{array}$ & $\begin{array}{l}0.20 \pm 0.010^{\mathrm{a}} \\
0.25 \pm 0.007^{\mathrm{b}}\end{array}$ & $\begin{array}{l}2.50 \pm 0.070^{b} \\
3.50 \pm 0.070^{c}\end{array}$ \\
\hline Penicillium aurantiogriseum & $\begin{array}{l}0.20 \pm 0.010^{\mathrm{a}} \\
0.40 \pm 0.000^{\mathrm{a}}\end{array}$ & $\begin{array}{l}0.10 \pm 0.010^{\mathrm{b}} \\
0.20 \pm 0.010^{\mathrm{b}}\end{array}$ & $\begin{array}{l}0.20 \pm 0.000^{b} \\
0.30 \pm 0.020^{c}\end{array}$ \\
\hline
\end{tabular}

In each row different letters mean significant differences $(p<0.05)$. 
B. cereus with the same MICs $(0.0125 \mathrm{mg} / \mathrm{mL})$ and MBCs $(0.035 \mathrm{mg} /$ $\mathrm{mL})$. E. cloacae strain was the most resistant to the effect of M. giganteus extract with MIC of $2.50 \mathrm{mg} / \mathrm{mL}$ and MBC of $5.00 \mathrm{mg} /$ $\mathrm{mL}$. It should be noted that the most sensitive bacterial strains were
Gram positive. Although, M. flavus (Gram positive) and P. aeruginosa (Gram negative) had the same inhibitory and bactericidal values $(0.60 \mathrm{mg} / \mathrm{mL}$ and $1.25 \mathrm{mg} / \mathrm{mL}$ ), it might be suggested that the antimicrobial activity is dependent on bacterial species used. The

Table 4

Cytotoxic activity of $M$. giganteus methanolic extract (mean \pm SD) on HeLa and MRC-5 cell lines.

\begin{tabular}{|c|c|c|c|c|c|}
\hline & & \multicolumn{2}{|c|}{ Extract $(\mathrm{mg} / \mathrm{mL})$} & \multicolumn{2}{|c|}{ Doxorubicin $(\mathrm{mg} / \mathrm{mL})$} \\
\hline & & $24 \mathrm{~h}$ & $48 \mathrm{~h}$ & $24 \mathrm{~h}$ & $48 \mathrm{~h}$ \\
\hline \multirow[t]{2}{*}{ HeLa } & $\mathrm{IC}_{50}$ & $0.72 \pm 0.27^{b}$ & $0.41 \pm 0.08^{b}$ & $0.0069 \pm 0.0006^{a}$ & $0.0027 \pm 0.0003^{a}$ \\
\hline & $\mathrm{IC}_{80}$ & $1.32 \pm 0.23^{\mathrm{b}}$ & $0.80 \pm 0.04^{\mathrm{b}}$ & $0.0091 \pm 0.0010^{a}$ & $0.0039 \pm 0.0007^{a}$ \\
\hline \multirow[t]{2}{*}{ MRC-5 } & $\mathrm{IC}_{50}$ & $>1.6$ & $>1.6$ & $0.0059 \pm 0.0012$ & $0.0025 \pm 0.0004$ \\
\hline & $\mathrm{IC}_{80}$ & na & na & $0.0091 \pm 0.0022$ & $0.0046 \pm 0.0005$ \\
\hline
\end{tabular}

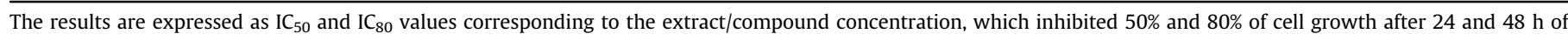

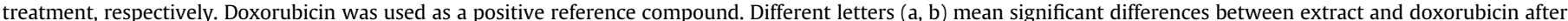
$24 \mathrm{~h}$ and $48 \mathrm{~h}$ of treatment, respectively ( $\mathrm{p} \leq 0.05)$. Na-not acquired.
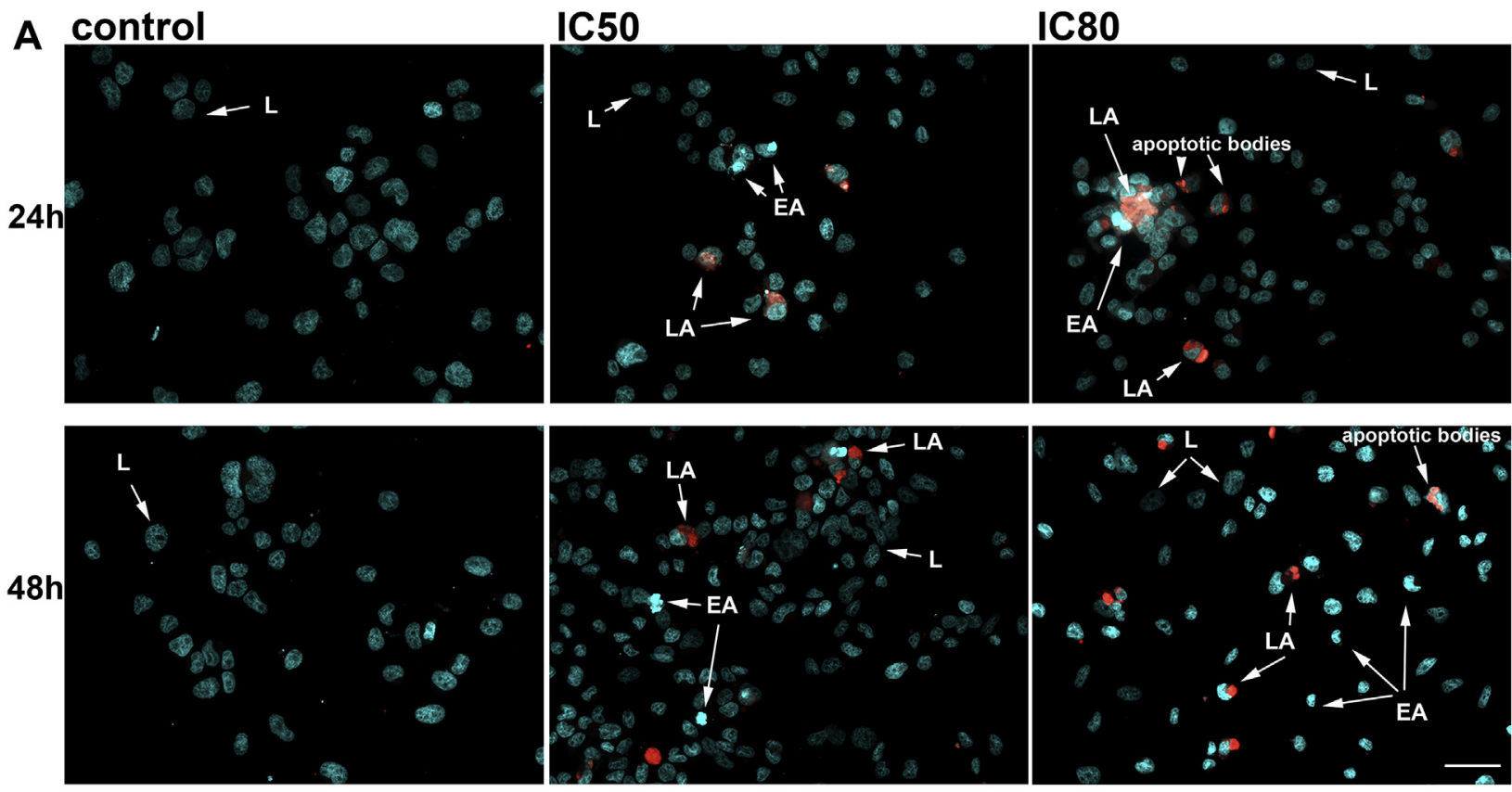

B

\section{C}
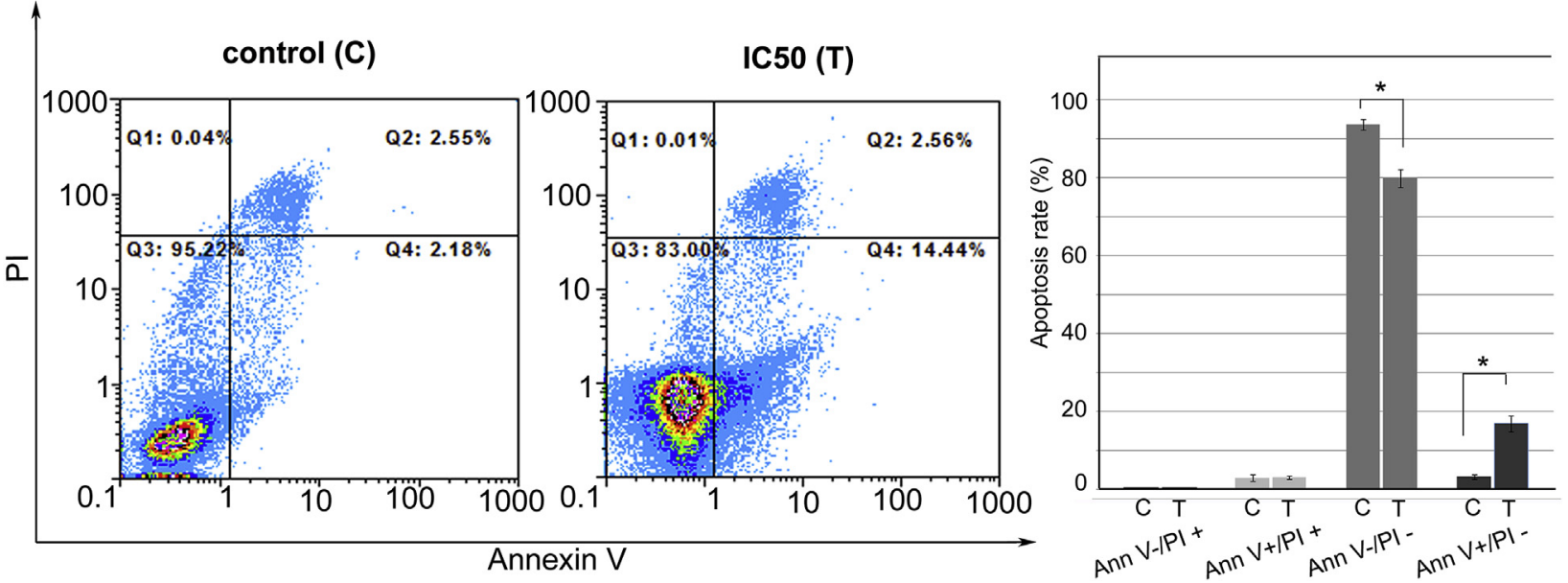

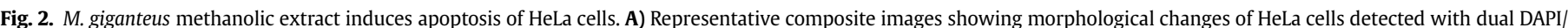

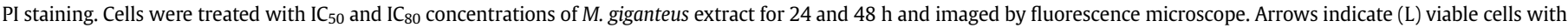

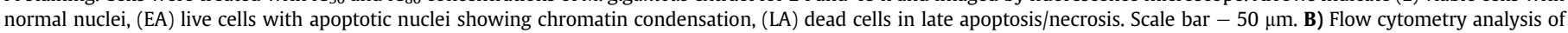

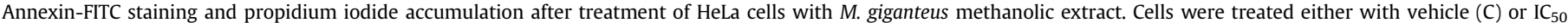

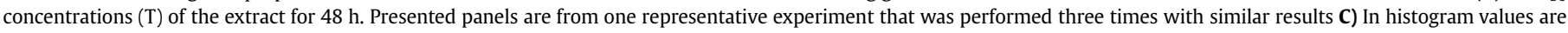
expressed as mean \pm SEM of three independent experiments. Values of $P<0.01$ are presented by asterisks. 
activity of the extract decreased in order: S. aureus $=$ B. cereus $>$ S. typhimurium $>$ E. coli $>$ L. monocytogenes $>$ M. flavus $=$ P. aeruginosa $>$ E. cloacae. Karaman et al. (2010), even though applying different method, also found $S$. aureus strain as the most sensitive to the antimicrobial action of $M$. giganteus.

Regarding antifungal activity, A. versicolor and $P$. funiculosum were the most susceptible micromycetes with MICs of $0.025 \mathrm{mg} / \mathrm{mL}$ and MFCs of $0.050 \mathrm{mg} / \mathrm{mL}$. A. niger was the most resistant strain with MIC of $0.30 \mathrm{mg} / \mathrm{mL}$ and MFC of $0.40 \mathrm{mg} / \mathrm{mL}$. Antifungal activity of the tested sample decreased in order: A. versicolor $=P$. funiculosum $>T$. viride $>A$. fumigatus $>$ A. ochraceus $=P$. ochrochloron $=P$. aurantiogriseum $>A$. niger. In general, fungi were more sensitive than bacteria to the effect of $M$. giganteus extract. To the best of our knowledge, no previous studies reported antifungal activity of M. giganteus. Standard antibiotics (streptomycin and ampicillin) and antimycotics (bifonazole and ketoconazole) were used as positive controls, but comparison with $M$. giganteus extract should be avoided, since the extract presents a mixture of compounds in which the concentration of each bioactive compound is much lower than the MIC. Antimicrobial activity could be related to the presence of the phenolic acids identified in the extract that also show antimicrobial properties against bacteria and fungi (Heleno et al., 2013).

\subsubsection{Evaluation of cytotoxic properties on HeLa cells}

The effect of $M$. giganteus methanolic extract on the proliferation and viability of HeLa cells was assessed using MTT assay. A dosedependent growth inhibition was observed in HeLa cell line after treatment with the extract for $24 \mathrm{~h}$ and $48 \mathrm{~h}$. Extract concentrations required for $50 \%$ inhibition of growth ( $\mathrm{IC}_{50}$ ) were $0.72 \mathrm{mg} / \mathrm{mL}$ and $0.41 \mathrm{mg} / \mathrm{mL}$ for 24 and $48 \mathrm{~h}$ of treatment, respectively (Table 4 ). The concentrations required for $80 \%$ of growth inhibition (IC 80 ) were $1.32 \mathrm{mg} / \mathrm{mL}$ and $0.80 \mathrm{mg} / \mathrm{mL}$ for $24 \mathrm{~h}$ and $48 \mathrm{~h}$, respectively. These results are consistent with two previously published showing that $M$. giganteus methanolic extract displays cytotoxicity against human breast carcinoma cells MCF-7 (with similar range of $\mathrm{IC}_{50}$ concentrations) and against murine Lewis lung carcinoma cell line 3LL (Karaman et al., 2009; Tomasi, Lohezic-Le Devehat, Sauleau, Bezivin, \& Boustie, 2004). Methanolic extract of M.giganteus did not cause $50 \%$ inhibition of growth $\left(\mathrm{IC}_{50}\right)$ of normal fibroblast cell line MRC-5, even at the highest concentration tested $(1.6 \mathrm{mg} / \mathrm{mL}$, Table 4).
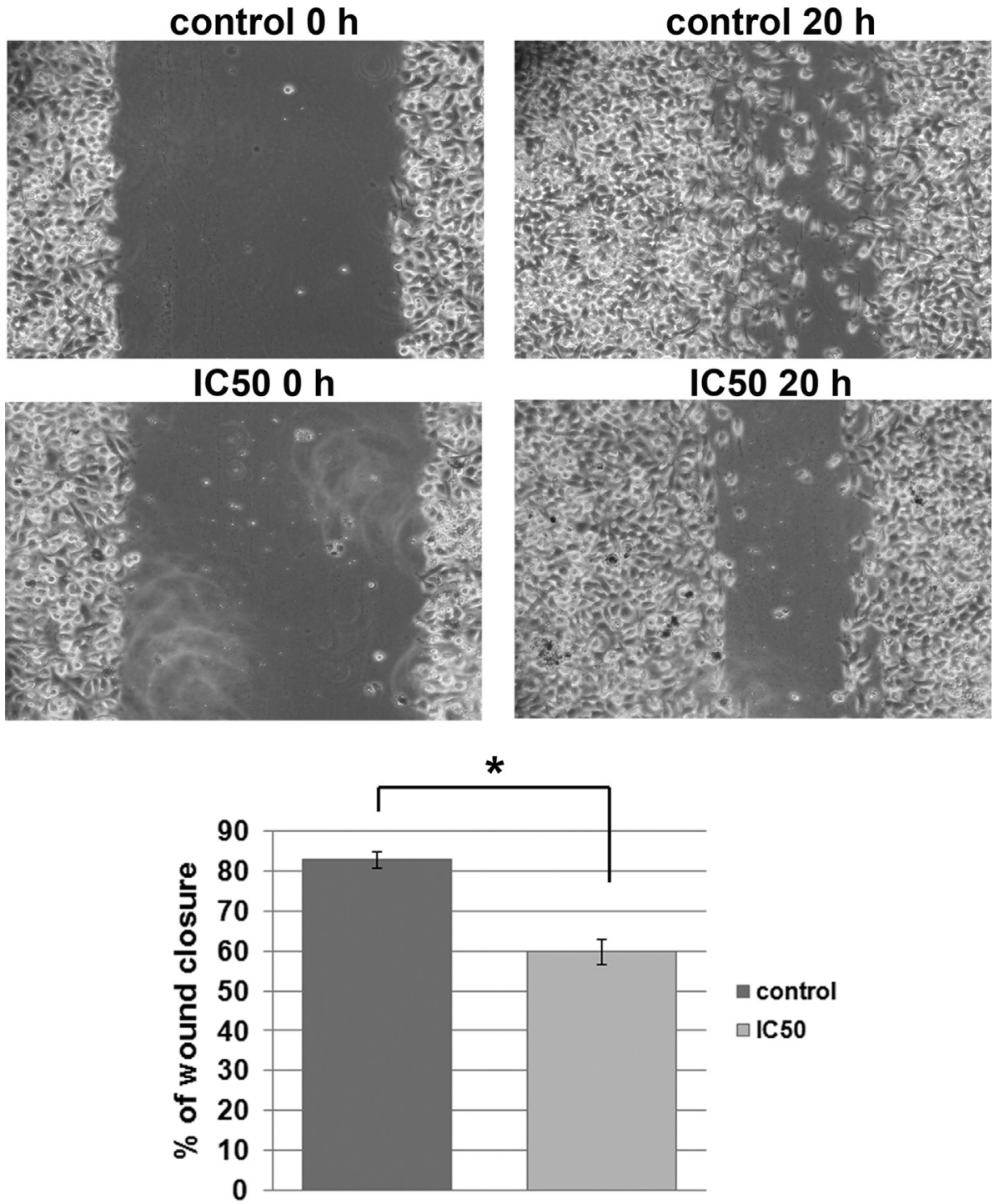

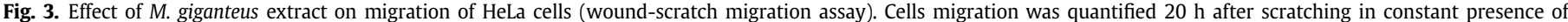

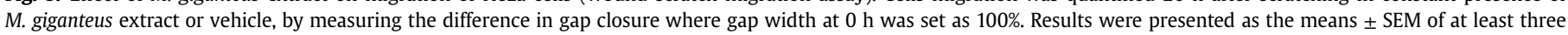
independent experiments. Value of $P<0.001$ is presented by an asterisk. 
These results suggest the presence of bioactive compounds that impair cell growth in the analyzed extract. The identified phenolic acids could be, at least partly, responsible for this property. $p$ Coumaric acid, most abundant phenolic component of $M$. giganteus methanolic extract, was previously shown to inhibit proliferation and induce apoptosis of colorectal adenocarcinoma cell lines (HCT15 and HT-29) (Jaganathan, Supriyanto, \& Mandal, 2013). Cytotoxic activity on several malignant cell lines was also demonstrated for cinnamic acid and its derivatives (Sova et al., 2013).

\subsubsection{Induction of apoptosis of HeLa cells}

First we have observed morphological changes in HeLa cells nuclei after treatment with $M$. giganteus extract using double staining with DAPI and PI. Cells treated with M. giganteus extract for 24 or $48 \mathrm{~h}$ exhibited typical features of apoptosis such as nuclear condensation, fragmentation and formation of apoptotic bodies (Fig. 2A). Cells in early apoptosis have highly condensed chromatin that is characterized by more intense blue fluorescence compared to the nuclei of healthy cells, while cells in late apoptosis/necrosis have lost the integrity of their plasma membranes and their condensed/fragmented chromatin is characterized by bright red fluorescence. Observed morphological changes suggest that mechanism underlying inhibition of cell growth by $M$. giganteus extract relies on induction of apoptosis. This mode of action has been demonstrated previously for many mushroom extracts and their bioactive principles (Popović et al., 2013).

These results were confirmed by flow cytometry (Fig. 2B and C). Obtained results suggested that $M$. giganteus methanolic extract induced early apoptosis in HeLa cells (Annexin+/PI-). Based on three independent experiments the percentage of cells in early apoptosis raised to $17 \%$ compared to control cells treated with vehicle only (Fig. 2C). At the same time, the low percentage of cells with necrosis (Annexin-/PI+) and late apoptosis (Annexin+/PI+) remained unchanged. Taken together, these results suggest that $M$. giganteus extract induced apoptosis of HeLa cells.

\subsubsection{The effect on migratory potential of HeLa cells}

Since the ability of cancer cells to migrate is closely associated with their capacity to colonize distant organs, we tested migratory potential of HeLa cells, upon treatment with M. giganteus extract, using wound scratch assays. We detected that treated HeLa cells were slower in closing the scratched area than control cells (Fig. 3), showing that $M$. giganteus extract exhibits not only cytotoxic, but also antimigratory effect on HeLa cells.

Antimigratory potential of mushroom's extracts has been reported for other classes like Fomitopsis pinicola which belongs to the Basidiomycota fungal class that could inhibit the migration of colon cancer cell line SW-480 (Wang et al., 2014), or Ganoderma lucidum that exerts strong antimigratory effect on ovarian cancer cell lines (Zhao et al., 2011). This is the first report presenting antimigratory potential of $M$. giganteus extract on cancer cells in vitro.

\section{Conclusions}

Chemical composition analysis of $M$. giganteus methanolic extract revealed the presence of bioactive compounds (all tocopherol isoforms, five organic and three phenolic acids) along with carbohydrates, fatty acids and proteins. Trehalose was identified as the predominant free sugar. Polyunsaturated fatty acids predominated over monounsaturated and saturated fatty acids, highlighting linoleic acid as the most dominant one. M. giganteus is a natural source of agents exhibiting antioxidant, antimicrobial and antitumor activities highlighting this species as a valuable dietary supplement in chemoprevention. Importantly, $M$. giganteus extract was not toxic for zebrafish embryos indicating its biosafety and potential for further applications in food or pharmaceutical industry.

\section{Acknowledgements}

This work was supported by the Ministry of Education, Science and Technological Development of the Republic of Serbia (grant numbers 173032, 173051 and 47025). Authors are grateful to the Foundation for Science and Technology (FCT, Portugal) for financial support to CIMO (Pest-OE/AGR/UI0690/2015) and L. Barros grant (SFRH/BPD/107855/2015). We would like to thank dr Jelena Dinic for help in performing DAPI/PI staining.

\section{Appendix A. Supplementary data}

Supplementary data related to this article can be found at http:// dx.doi.org/10.1016/j.lwt.2017.01.045.

\section{References}

Alves, M. J., Ferreira, I. C. F. R., Dias, J., Teixeira, V., Martins, A., \& Pintado, M. (2013). A review on antifungal activity of mushroom (basidiomycetes) extracts and isolated compounds. Current Topics in Medicinal Chemistry, 13, 2648-2659.

Assaf, A. M., Haddadin, R. N., Aldouri, N. A., Alabbassi, R., Mashallah, S., Mohammad, M., et al. (2013). Anti-cancer, anti-inflammatory and antimicrobial activities of plant extracts used against hematological tumors in traditional medicine of Jordan. Journal of Ethnopharmacology, 145, 728-736.

Barros, L., Dueñas, M., Ferreira, I. C. F. R., Baptista, P., \& Santos-Buelga, C. (2009), Phenolic acids determination by HPLC-DAD-ESI/MS in sixteen different Portuguese wild mushrooms species. Food and Chemical Toxicology, 47, 1076-1079.

Barros, L., Pereira, C., \& Ferreira, I. C. F. R. (2013). Optimized analysis of organic acids in edible mushrooms from Portugal by ultra fast liquid chromatography and photodiode array detection. Food Analytical Methods, 6, 309-316.

Bjelakovic, G., Nikolova, D., \& Gluud, C. (2014). Antioxidant supplements and mortality. Current Opinion in Clinical Nutrition and Metabolic Care, 17, 40-44.

Choque, B., Catheline, D., Rioux, V., \& Legrand, P. (2014). Linoleic acid: Between doubts and certainties. Biochimie, 96, 14-21.

CLSI. Clinical and Laboratory Standards Institute. (2009). Methods for dilution antimicrobial susceptibility tests for bacteria that grow aerobically. Approved standard (8th ed.). Wayne, PA: CLSI publication M07-A8. Clinical and Laboratory Standards Institute.

Ferreira, I. C. F. R., Barros, L., \& Abreu, R. M. V. (2009). Antioxidants in wild mushrooms. Current Medicinal Chemistry, 16, 1543-1560.

Heleno, S. A., Barros, L., Sousa, M. J., Martins, A., \& Ferreira, I. C. F. R. (2010). Tocopherols composition of Portuguese wild mushrooms with antioxidant capacity. Food Chemistry, 119, 1443-1450.

Heleno, S. A., Ferreira, I. C. F. R., Calhelha, R. C., Esteves, A. P., Ćirić, A., Glamočlija, J., et al. (2013). Antimicrobial and demelanizing activity of Ganoderma lucidum extract, $p$-hydroxybenzoic and cinnamic acids and their synthetic acetylated glucuronide methyl esters. Food and Chemical Toxicology, 58, 95-100.

Jaganathan, S. K., Supriyanto, E., \& Mandal, M. (2013). Events associated with apoptotic effect of $p$-Coumaric acid in HCT-15 colon cancer cells. World Journal of Gastroenterology, 19, 7726-7734.

Kalač, P. (2013). A review of chemical composition and nutritional value of wildgrowing and cultivated mushrooms. Journal of the Science of Food and Agriculture, 93, 209-218.

Kancheva, V. D., \& Kasaikina, O. T. (2013). Bio-antioxidants - a chemical base of their antioxidant activity and beneficial effect on human health. Current Medicinal Chemistry, 20, 4784-4805.

Karaman, M., Jovin, E., Malbaša, R., Matavuly, M., \& Popovic, M. (2010). Medicinal and edible lignicolous fungi as natural sources of antioxidative and antibacterial agents. Phytotherapy Research, 24, 1473-1481.

Karaman, M., Kaisarevic, S., Somborski, J., Kebert, M., \& Matavulj, M. (2009). Biological activities of the lignicolous fungus Meripilus giganteus (Pers.: Pers) Karst. Archive of Biological Sciences, 61, 853-861.

Mager, D. L. (2006). Bacteria and cancer: Cause, coincidence or cure? A review. Journal of Translational Medicine, 4, 14.

Popović, V., Živković, J., Davidović, S., Stevanović, M., \& Stojković, D. (2013). Mycotherapy of cancer: An update on cytotoxic and antitumor activities of mushrooms, bioactive principles and molecular mechanisms of their action. Current Topics in Medicinal Chemistry, 13, 2791-2806.

Schmidt, O. (2006). Wood and tree fungi: biology, damage, protection, and use. Berlin: Springer.

Sova, M., Zizak, Z., Stankovic, J. A., Prijatelj, M., Turk, S., Juranic, Z. D., et al. (2013). Cinnamic acid derivatives induce cell cycle arrest in carcinoma cell lines, Medical Chemistry, 9, 633-641.

Tomasi, S., Lohezic-Le Devehat, F., Sauleau, P., Bezivin, C., \& Boustie, J. (2004). Cytotoxic activity of methanol extracts from Basidiomycete mushrooms on murine cancer cell lines. Pharmazie, 59, 290-293. 
Wang, Y., Cheng, X., Wang, P., Wang, L., Fan, J., Wang, X., et al. (2014). Investigating migration inhibition and apoptotic effects of Fomitopsis pinicola chloroform extract on human colorectal cancer SW-480 Cells. PLoS One, 9, e101303.
Zhao, S., Ye, G., Fu, G., Cheng, J. X., Yang, B. B., \& Peng, C. (2011). Ganoderma lucidum exerts anti-tumor effects on ovarian cancer cells and enhances their sensitivity to cisplatin. International Journal of Oncology, 38, 1319-1327. 